\title{
Country tobacco laws and article 11 of the WHO Framework Convention on Tobacco Control: a review of tobacco packaging and labeling regulations of 25 countries
}

\author{
Ayodeji J Awopegba* and Joanna E Cohen
}

\begin{abstract}
Background: Urgent, evidence-based tobacco control efforts have been advocated by the WHO through the Framework Convention on Tobacco Control (FCTC) articles and guidelines. The level of implementation of these guidelines varies by country and region. This paper identifies areas of alignment and non-alignment of country tobacco laws with respect to the FCTC's article 11 requirements, which lists guidelines for regulating tobacco packaging and labeling.
\end{abstract}

Methods: Countries from each of the six WHO regions were ranked by number of smokers and 25 countries were selected, representing countries from all WHO regions with the highest number of smokers. A scoring guide based on the FCTC article 11 requirements was created and used to rank country tobacco laws and assess levels of alignment as well as identify common areas of weakness and strength.

Results: Across the countries examined, laws were generally strong in mandating the display of health warning messages on the front and back of cigarette packs and cartons. However, they were deficient in prohibiting the display of emission yields, and placing warnings at the top of the principal display area, as well as requiring health messages on tobacco's negative social and economic outcomes.

Conclusion: Country tobacco packaging and labeling laws can be strengthened by greater compliance with the FCTC article 11 guidelines.

Keywords: FCTC, Tobacco control, Tobacco packaging and labeling, Health warnings, Compliance

\section{Background}

Tobacco use remains the leading, single most preventable cause of death globally; the current annual death rate attributable to tobacco use stands at about 5.4 million deaths per year and is projected to increase to more than 8 million deaths annually by 2030 if urgent tobacco control efforts are not instituted [1]. The Framework Convention on Tobacco Control (FCTC), created to respond to the looming tobacco epidemic, as well as protect and promote global public health, articulates provisions that aim to reduce the supply and demand of tobacco globally. Adopted in November 2008, Article 11

\footnotetext{
* Correspondence: aawopegb@jhsph.edu

Institute for Global Tobacco Control, Johns Hopkins Bloomberg School of Public Health, Baltimore, MD, USA
}

\section{Ciomed Central}

guidelines [2] lists provisions for the regulation of tobacco product packaging and labeling.

Tobacco companies are increasingly using the cigarette package as a primary marketing vehicle, as is evident from this statement from the industry: "Our final communication vehicle with our smoker is the pack itself. In the absence of any other marketing messages, our packaging...is the sole communicator of our essence" [3]. The significant advertising potential of the cigarette packet is underscored by the persistent push back of the tobacco industry against plain packaging and other measures to reduce tobacco use [4].

Strong health warning messages can influence the decision to initiate or quit smoking [5,6], and these measures can be implemented at virtually no cost to 
government [7]. In addition, there is strong public support for strong health warnings, even among smokers [8-12]. However, it is not clear the extent to which countries are enacting strong tobacco packaging regulations that are consistent with the FCTC article 11 guidelines. This paper assesses the level of compliance of country tobacco laws with the mandatory components of the FCTC article 11 guidelines, and identifies common areas of weakness in tobacco labeling laws in the countries that contribute the most to the global burden from smoking across all six WHO regions.

\section{Methods}

\section{Country selection}

Countries with the highest numbers of smokers in each WHO region were selected for this study. Absolute number of smokers for each country was estimated from ageand sex-standardized adult daily smoking prevalence for the year 2009 [7] and country total population for 2010 [13]. Countries in each WHO region were ranked, from highest to lowest, by estimated number of smokers. The first six countries in the European Region, as well as the first five countries in each of other $\mathrm{WHO}$ regions were

Table 1 Characteristics of country laws, with respect to location of health warnings on cigarette packs

\begin{tabular}{|c|c|c|c|c|c|c|c|c|}
\hline${ }^{*}$ Country & $\begin{array}{l}\text { Ratified } \\
\text { FCTC }\end{array}$ & $\begin{array}{l}\text { Year of } \\
\text { ratification }\end{array}$ & $\begin{array}{l}\text { Warning on pack } \\
\text { and carton }\end{array}$ & $\begin{array}{l}\text { Front and } \\
\text { back }\end{array}$ & Top of PDA & $\begin{array}{l}\text { Opening does not } \\
\text { damage warning }\end{array}$ & $\begin{array}{l}\text { Not obstructed by } \\
\text { tax stamps, etc. }\end{array}$ & Total \\
\hline \multicolumn{9}{|l|}{ Africa } \\
\hline South Africa & YES & 2005 & 1 & 1 & 1 & 1 & 0 & 4 \\
\hline Kenya & YES & 2004 & 1 & 1 & 0 & 0 & 0 & 2 \\
\hline \multicolumn{9}{|l|}{ Americas } \\
\hline Mexico & YES & 2004 & 1 & 1 & 1 & 1 & 1 & 5 \\
\hline Canada & YES & 2004 & 1 & 1 & 0 & 1 & 1 & 4 \\
\hline Brazil & YES & 2005 & 1 & 1 & 0 & 0 & 1 & 3 \\
\hline Argentina & NO & & 1 & 1 & 0 & 0 & 1 & 3 \\
\hline USA & NO & & 1 & 1 & 1 & 0 & 0 & 3 \\
\hline \multicolumn{9}{|c|}{ Eastern Mediterranean } \\
\hline Egypt & YES & 2005 & 1 & 1 & 0 & 0 & 0 & 2 \\
\hline Pakistan & YES & 2004 & 1 & 1 & 1 & 0 & 0 & 3 \\
\hline \multicolumn{9}{|l|}{ Europe } \\
\hline Spain & YES & 2005 & 1 & 1 & 1 & 1 & 1 & 5 \\
\hline Turkey & YES & 2004 & 1 & 1 & 1 & 1 & 1 & 5 \\
\hline Poland & YES & 2006 & 1 & 1 & 0 & 1 & 1 & 4 \\
\hline UK & YES & 2004 & 1 & 1 & 0 & 1 & 1 & 4 \\
\hline Ukraine & YES & 2006 & 1 & 1 & 0 & 1 & 1 & 4 \\
\hline Russia & YES & 2008 & 0.5 & 1 & 0 & 1 & 0 & 2.5 \\
\hline \multicolumn{9}{|c|}{ South-East Asia } \\
\hline Nepal & YES & 2006 & 1 & 1 & 1 & 1 & 1 & 5 \\
\hline Thailand & YES & 2004 & 1 & 1 & 1 & 0 & 0 & 3 \\
\hline India & YES & 2004 & 1 & 1 & 0 & 1 & 1 & 4 \\
\hline Bangladesh & YES & 2004 & 1 & 1 & 1 & 0 & 0 & 3 \\
\hline Indonesia & NO & & 0.5 & 0.5 & 0 & 0 & 0 & 1 \\
\hline \multicolumn{9}{|c|}{ Western Pacific } \\
\hline Australia & YES & 2004 & 1 & 1 & 1 & 1 & 1 & 5 \\
\hline Malaysia & YES & 2005 & 1 & 1 & 1 & 0 & 1 & 4 \\
\hline Philippines & YES & 2005 & 1 & 1 & 0 & 1 & 1 & 4 \\
\hline VietNam & YES & 2004 & 1 & 1 & 0 & 0 & 0 & 2 \\
\hline China & YES & 2005 & 1 & 1 & 0 & 0 & 0 & 2 \\
\hline
\end{tabular}

*Countries are ranked within each of the six WHO regions by overall level of compliance with FCTC article 11 guidelines. 
selected to give a sample with the highest contribution to the global burden of smoking across all WHO regions. In instances where country laws were not available, or where verified translations were not accessible electronically, the next country on the list was selected, provided the numbers of smokers in both countries were comparable. In the African and Eastern Mediterranean regions, where these numbers were far apart, fewer countries were selected. This led to a final selection of 25 countries: six countries in the European region, five countries in the Americas, South-East Asia and Western Pacific regions, and two countries in the African and Eastern Mediterranean regions.

The countries by region are as follows: Africa (South Africa, Kenya); The Americas (Mexico, Canada, Brazil, Argentina, USA); South-East Asia (Nepal, Thailand, India, Bangladesh, Indonesia); Europe (Spain, Turkey, Poland, United Kingdom, Ukraine, Russia); Eastern Mediterranean (Pakistan, Egypt) and Western Pacific (Australia, Malaysia, Philippines, Vietnam, China).

\section{Scoring criteria}

We examined the FCTC article guidelines and distinguished required guidelines from optional recommendations by careful examination of how they were worded. Required guidelines were considered those that used words such as "must", "should", or "shall"; while optional guidelines were classified as those that used words such as "may" or "can", or contained phrases like "Parties should consider...".

The resulting scoring criteria contained 19 mandatory health warning components grouped under the following five categories: location, size, message content, language and display of misleading descriptors. We also assessed optional recommendations such as the use of pictograms, contrast, and the provision of a "quit line" number.

We used the scoring criteria thus created to assess each country's compliance with FCTC article 11 guidelines on tobacco packaging and labeling. We extracted country tobacco laws from the Campaign for TobaccoFree Kids website www.tobaccocontrollaws.org [14], as this was considered a reliable source of verified translations of the tobacco packaging and labeling laws of different countries. We awarded one point for meeting each required guideline and one-half point where guidelines partially complied with the FCTC requirements. If a country's laws did not precisely reflect what the FCTC guidelines specify, no point was awarded. Thus, higher total scores indicate greater alignment of the laws with the guidelines.

\section{Analysis}

Scores across all article 11 requirements were totaled for each country to reflect the overall level of alignment with the guidelines. Within WHO Regions, countries were ranked from highest to lowest total score.

\section{Results}

Out of a maximum of 19 points, total scores ranged from 18 (Australia) to 4 (Indonesia). Three countries in the selection (USA, Argentina and Indonesia) have not ratified the FCTC. Across all countries examined, laws were generally strong in requiring that health warning messages are

Table 2 Characteristics of country laws, with respect to size of health warnings on cigarette packs

\begin{tabular}{|c|c|c|c|}
\hline${ }^{*}$ Country & $\begin{array}{l}\text { Not less than } \\
30 \% \text { of PDAs }\end{array}$ & $\begin{array}{l}\text { Bold, legible } \\
\text { text }\end{array}$ & Total \\
\hline \multicolumn{4}{|l|}{ Africa } \\
\hline South Africa & 0 & 1 & 1 \\
\hline Kenya & 1 & 1 & 2 \\
\hline \multicolumn{4}{|l|}{ Americas } \\
\hline Mexico & 1 & 1 & 2 \\
\hline Canada & 1 & 1 & 2 \\
\hline Brazil & 1 & 1 & 2 \\
\hline Argentina & 1 & 1 & 2 \\
\hline USA & 1 & 1 & 2 \\
\hline \multicolumn{4}{|c|}{ Eastern Mediterranean } \\
\hline Egypt & 1 & 1 & 2 \\
\hline Pakistan & 1 & 1 & 2 \\
\hline \multicolumn{4}{|l|}{ Europe } \\
\hline Spain & 1 & 1 & 2 \\
\hline Turkey & 1 & 0 & 1 \\
\hline Poland & 1 & 1 & 2 \\
\hline UK & 1 & 1 & 2 \\
\hline Ukraine & 1 & 0 & 1 \\
\hline Russia & 1 & 0 & 1 \\
\hline \multicolumn{4}{|c|}{ South-East Asia } \\
\hline Nepal & 1 & 1 & 2 \\
\hline Thailand & 1 & 1 & 2 \\
\hline India & 1 & 1 & 2 \\
\hline Bangladesh & 1 & 1 & 2 \\
\hline Indonesia & 0 & 1 & 1 \\
\hline \multicolumn{4}{|c|}{ Western Pacific } \\
\hline Australia & 1 & 1 & 2 \\
\hline Malaysia & 1 & 1 & 2 \\
\hline Philippines & 1 & 1 & 2 \\
\hline VietNam & 1 & 1 & 2 \\
\hline China & 1 & 0 & 1 \\
\hline
\end{tabular}

${ }^{*}$ Countries are ranked within each of the six WHO regions by overall level of compliance with FCTC article 11 guidelines. 
displayed on the front and back of cigarette packs and cartons. However, they were generally weak in prohibiting the display of emission yields, and placing warnings at the top of the principal display area (which is, in most cases, the front and back, or the widest part of the package), as well as requiring health messages on tobacco's negative social and economic outcomes.

Table 3 Characteristics of country laws, with respect to prohibition of misleading descriptors on cigarette packs

\begin{tabular}{|c|c|c|c|c|}
\hline${ }^{*}$ Country & $\begin{array}{l}\text { Prohibition of } \\
\text { term, descriptor, } \\
\text { trademark or } \\
\text { figurative or } \\
\text { other sign that } \\
\text { may be deceptive }\end{array}$ & $\begin{array}{l}\text { Prohibition } \\
\text { of display } \\
\text { of emission } \\
\text { yields }\end{array}$ & $\begin{array}{l}\text { Display of } \\
\text { relevant } \\
\text { qualitative } \\
\text { emissions } \\
\text { such as } \\
\text { benzene }\end{array}$ & $\overline{\text { Total }}$ \\
\hline
\end{tabular}

Africa

South Africa 1

Kenya $\quad 0$

Americas

Mexico

Canada

Brazil $\quad 0.5$

Argentina 1

USA $\quad 0$

Eastern

Mediterranean

Egypt $\quad 0.5$

Pakistan 0

Europe

Spain 1

Turkey 1

Poland 1

UK $\quad 1$

Ukraine $\quad 1$

Russia $\quad 0$

South-East Asia

Nepal 1

Thailand 1

India 1

Bangladesh 0

Indonesia 0

Western Pacific

\begin{tabular}{lllll} 
Australia & 1 & 1 & 1 & 3 \\
Malaysia & 0.5 & 0 & 1 & 1.5 \\
Philippines & 0 & 0 & 0 & 0 \\
VietNam & 1 & 0 & 0 & 1 \\
China & 0.5 & 0 & 0 & 0.5 \\
\hline${ }^{*}$ Countries are
\end{tabular}

*Countries are ranked within each of the six WHO regions by overall level of compliance with FCTC article 11 guidelines.

\section{Results by category}

\section{Location}

Most countries $(\mathrm{n}=23)$ in the selection required warnings on both packs and cartons, except Russia and Indonesia, that did not require health warnings on cartons (Table 1). Less than half of the countries in the selection $(n=11)$ required that warnings are placed at the top of the principal display area (PDA). Brazil, Indonesia, Philippines and India required warnings to be placed on only one PDA. Kenya, Egypt, Indonesia, China, Vietnam did not mandate that

Table 4 Characteristics of country laws, with respect to rotation of health warnings

\begin{tabular}{lllll}
\hline *Country & $\begin{array}{l}\text { Rotation } \\
\text { required }\end{array}$ & $\begin{array}{l}\text { Rotation } \\
\text { format } \\
\text { specified }\end{array}$ & $\begin{array}{l}\text { Range of packs } \\
\text { to which rotation } \\
\text { is applicable is } \\
\text { specified }\end{array}$ & Total \\
\hline Africa & & & & 3 \\
South Africa & 1 & 1 & 1 & 3 \\
Kenya & 1 & 1 & 1 & \\
Americas & & & & 3 \\
Mexico & 1 & 1 & 1 & 3 \\
Canada & 1 & 1 & 1 & 2 \\
Brazil & 1 & 1 & 0 & 3 \\
Argentina & 1 & 1 & 1 & 1 \\
USA & 1 & 0 & 0 &
\end{tabular}

Eastern Mediterranean

$\begin{array}{lllll}\text { Egypt } & 1 & 1 & 0 & 2\end{array}$

$\begin{array}{lllll}\text { Pakistan } & 1 & 1 & 1 & 3\end{array}$

Europe

Spain

Turkey

Poland

UK

Ukraine

Russia

South-East Asia

Nepal

Thailand

India

Bangladesh

Indonesia

Western Pacific

$\begin{array}{lllll}\text { Australia } & 1 & 1 & 1 & 3\end{array}$

Malaysia 1

Philippines 1

VietNam

China

${ }^{*}$ Countries are ranked within each of the six WHO regions by overall level of compliance with FCTC article 11 guidelines. 
health warnings be placed at the top of the PDA, or placed where they would not be damaged by opening the pack, or that they are positioned where they would not be obstructed by mandatory markings on the packs. In this selection, Mexico, Spain, Turkey Nepal and Australia were the most compliant with regard to the requirements on location, scoring the maximum points for this category, while Indonesia ranked least.

\section{Size}

Most countries were generally compliant with the requirements on size. South Africa and Indonesia were the only countries in this analysis whose health warnings were not required to cover at least $30 \%$ of the principal display area (PDA) (Table 2).

\section{Misleading descriptors}

Countries generally aligned poorly with the FCTC guidelines by not prohibiting the display of emission yields, and by failing to require the display of relevant qualitative emissions like Benzene. Though Brazil, Egypt, Malaysia and China ban the display of misleading descriptors, they do not prohibit the stealthy use of colors, and other insignia that could give a false impression that one brand is safer than another (Table 3). Mexico and Australia were the most compliant, getting all points under the category

Table 5 Characteristics of country laws, with respect to message content of health warnings on cigarette packs

\begin{tabular}{|c|c|c|c|c|c|c|}
\hline${ }^{*}$ Country & $\begin{array}{l}\text { Advice on } \\
\text { health effects }\end{array}$ & Cessation & Addictive nature & $\begin{array}{l}\text { Adverse economic and } \\
\text { social outcomes }\end{array}$ & $\begin{array}{l}\text { Impact on family } \\
\text { and friends }\end{array}$ & Total \\
\hline \multicolumn{7}{|l|}{$\overline{\text { Africa }}$} \\
\hline South Africa & 1 & 1 & 1 & 0 & 1 & 4 \\
\hline Kenya & 1 & 0 & 0 & 0 & 1 & 2 \\
\hline \multicolumn{7}{|l|}{ Americas } \\
\hline Mexico & 1 & 0 & 1 & 0 & 1 & 3 \\
\hline Canada & 1 & 1 & 1 & 0 & 1 & 4 \\
\hline Brazil & 1 & 1 & 1 & 0 & 1 & 4 \\
\hline Argentina & 1 & 1 & 1 & 0 & 0 & 3 \\
\hline USA & 1 & 1 & 1 & 0 & 1 & 4 \\
\hline \multicolumn{7}{|c|}{ Eastern Mediterranean } \\
\hline Egypt & 1 & 0 & 1 & 1 & 1 & 4 \\
\hline Pakistan & 1 & 0 & 0 & 0 & 0 & 1 \\
\hline \multicolumn{7}{|l|}{ Europe } \\
\hline Spain & 1 & 1 & 1 & 1 & 1 & 5 \\
\hline Turkey & 1 & 1 & 1 & 0 & 1 & 4 \\
\hline Poland & 1 & 1 & 1 & 0 & 1 & 4 \\
\hline UK & 1 & 1 & 1 & 0 & 1 & 4 \\
\hline Ukraine & 1 & 0 & 1 & 1 & 1 & 4 \\
\hline Russia & 1 & 1 & 1 & 0 & 1 & 4 \\
\hline \multicolumn{7}{|c|}{ South-East Asia } \\
\hline Nepal & 1 & 0 & 0 & 0 & 0 & 1 \\
\hline Thailand & 1 & 0 & 0 & 0 & 1 & 2 \\
\hline India & 1 & 0 & 0 & 0 & 0 & 1 \\
\hline Bangladesh & 1 & 0 & 0 & 0 & 1 & 2 \\
\hline Indonesia & 1 & 0 & 0 & 0 & 0 & 1 \\
\hline \multicolumn{7}{|c|}{ Western Pacific } \\
\hline Australia & 1 & 1 & 1 & 0 & 1 & 4 \\
\hline Malaysia & 1 & 0 & 0 & 0 & 0 & 1 \\
\hline Philippines & 1 & 0 & 0 & 0 & 1 & 2 \\
\hline VietNam & 1 & 0 & 0 & 0 & 0 & 1 \\
\hline China & 1 & 0 & 0 & 0 & 0 & 1 \\
\hline
\end{tabular}

*Countries are ranked within each of the six WHO regions by overall level of compliance with FCTC article 11 guidelines. 
of prohibiting all forms of misleading descriptors on packs, whereas country tobacco laws from the USA, Pakistan, Russia, Bangladesh, Indonesia and the Philippines did not prohibit misleading descriptors, in any form, on packs and scored no points in this section.

\section{Rotation}

In this selection, only Indonesia and Bangladesh did not require health warnings to be rotated. Though rotation of health warnings was required by the rest, about half of country tobacco laws $(n=14)$ were still vague on the frequency of rotation, or the range of packs that the rotation sequence must apply to (Table 4).

\section{Message content}

In this selection, only Spain required health warnings that covered all five components of the requirements under the category "Message content". Most countries $(\mathrm{n}=22)$, except Spain, Ukraine and Egypt, did not require health warnings about the adverse economic and social outcomes related to smoking on their packs. All countries in this analysis required warnings that talked about the adverse health effects of smoking (Table 5).

\section{Language}

All countries' laws under review required that health warnings be printed in at least one of the principal language of the country, in alignment with the FCTC guidelines on article 11 .

\section{Optional recommendations}

In this selection, only South Africa, Mexico, Canada, Brazil, Argentina, Spain, Poland, the United Kingdom, Thailand, Australia and Malaysia provided a quit line number on their packs (Table 6). South Africa, Kenya, Poland, Indonesia, Philippines and China did not require graphic pictograms. Indonesia, China, Turkey and Ukraine did not explicitly state that warnings should use contrasting colors for the background of the text.

\section{Discussion}

This cross-country study of tobacco packaging and labeling laws showed that even countries that have ratified the FCTC are yet to align their laws to the highest standards of the FCTC article 11, especially with regard to the diversity of the content of health warnings, location of health warnings on the PDA of packs, and prohibition of misleading descriptors on cigarette packs.

It is important that health warning messages continue to reflect the extensiveness of the effects tobacco use can have on its users and those around them. Tobacco companies have historically obfuscated the facts about the addictive nature of nicotine, as well as the farreaching adverse effects of smoking on health and the
Table 6 Characteristics of country laws, with respect to optional health warning components of the FCTC

\begin{tabular}{lllll}
\hline *Country & Quit line & Pictograms & Contrast & To \\
\hline Africa & & & & \\
South Africa & 1 & 0 & 1 & 2 \\
Kenya & 0 & 0 & 1 & 1 \\
Americas & 1 & 1 & 1 & 3 \\
Mexico & 1 & 1 & 1 & 3 \\
Canada & 1 & 1 & 1 & 3 \\
Brazil & 1 & 1 & 1 & 3 \\
Argentina & 1 & 1 & 1 & 3 \\
USA & 1 & &
\end{tabular}

Eastern Mediterranean

$\begin{array}{lllll}\text { Egypt } & 0 & 1 & 1 & 2 \\ \text { Pakistan } & 0 & 1 & 1 & 2\end{array}$

Europe

$\begin{array}{lllll}\text { Spain } & 1 & 1 & 1 & 3\end{array}$

$\begin{array}{lllll}\text { Turkey } & 0 & 1 & 0 & 1\end{array}$

$\begin{array}{lllll}\text { Poland } & 1 & 0 & 1 & 2\end{array}$

$\begin{array}{lllll}\text { UK } & 1 & 1 & 1 & 3\end{array}$

$\begin{array}{lllll}\text { Ukraine } & 0 & 1 & 0 & 1\end{array}$

$\begin{array}{lllll}\text { Russia } & 0 & 1 & 1 & 2\end{array}$

South-East Asia

$\begin{array}{lllll}\text { Nepal } & 0 & 1 & 1 & 2\end{array}$

$\begin{array}{lllll}\text { Thailand } & 1 & 1 & 1 & 3\end{array}$

$\begin{array}{lllll}\text { India } & 0 & 1 & 1 & 2\end{array}$

$\begin{array}{lllll}\text { Bangladesh } & 0 & 1 & 1 & 2\end{array}$

$\begin{array}{lllll}\text { Indonesia } & 0 & 0 & 0 & 0\end{array}$

Western Pacific

$\begin{array}{lllll}\text { Australia } & 1 & 1 & 1 & 3\end{array}$

$\begin{array}{lllll}\text { Malaysia } & 1 & 1 & 1 & 3\end{array}$

$\begin{array}{lllll}\text { Philippines } & 0 & 0 & 1 & 1\end{array}$

$\begin{array}{lllll}\text { VietNam } & 0 & 1 & 1 & 2\end{array}$

$\begin{array}{lllll}\text { China } & 0 & 0 & 0 & 0\end{array}$

*Countries are ranked within each of the six WHO regions by overall level of compliance with FCTC article 11 guidelines.

environment [15]. Consequently, many smokers, including non-smokers, have underestimated the extreme addictive nature of nicotine and the impact of their smoking habit on their health and those around them $[16,17]$. A combination of warnings that cover issues on health effects of smoking with adverse social and economic outcomes, addictive nature of nicotine, cessation and the impact of smoking on family and friends, as required by the FCTC, can be more powerful in convincing individuals who differ in what motivates them to initiate or quit smoking. 
This study also detects a consistent weakness with respect to location of health warnings. Many countries do not require that health warnings be placed at the top of the principal display area. In addition, many country laws do not require health warnings to be located where they would not be obstructed by required markings on packs, or damaged/concealed with the opening and closing of packs. Most countries in the selection (except Mexico, Spain, Turkey, Nepal and Australia) do not meet all the requirements for location of health warning labels as required by the FCTC. Though large warnings have been shown to be effective by both smokers and non-smokers $[18,19]$, placing them at the top of the PDA can further enhance their effectiveness and noticeability.

Most country laws in the selection did not prohibit the use of all forms of misleading descriptors on packs, except Australia and Mexico, which comply with all the requirements of the FCTC with respect to this category. Countries' laws were especially weak in prohibiting the display of quantitative emission yields on their packs. Users of these products may still ascribe lower risks to brands that have lower levels of tar, carbon monoxide or nicotine, attenuating the effect that the prohibition of the use of misleading terms such as "mild" "light", may have had.

Six countries in the selection (South Africa, Kenya, Poland, Indonesia, Philippines and China) are yet to mandate the use of health warnings that contain pictograms. It is also important to note that most of these are low-and middle-income countries, where health literacy may be relatively low. Though the use of pictograms is not a requirement, countries can strengthen the impact of their warning labels by using graphic color images. Strong warnings that utilize graphic pictograms, and not just text, are shown to be more effective in getting the attention of users, conveying the significance of the text warning and ultimately inducing a change in the perception of risk by the users [18,20-27]. Studies have shown that smokers tend to notice health warnings with pictures more than they do warnings without [21,28]. Pictograms would convey a stronger message, especially in low-literacy settings, or in cases where text warnings are very weak in conveying the harms of tobacco use.

Strong health warning messages can influence the decision to initiate or quit smoking $[5,6]$, and these measures can be implemented at no cost to governments [7]. Some countries like Canada [19,29,30], Australia [11], Brazil [31], Singapore [32] and Thailand [33] have seen significant change in perceptions and attitudes toward smoking following implementation of some of these FCTC-recommended best-practices in health warning display. Barriers to implementing best practices in tobacco packaging and labeling, as stipulated by the FCTC, would vary by country. Countries should share their successes and challenges, and collaborate on possible strategies to strengthen their tobacco laws. Sustained efforts to enact, mandate and enforce the evidence-driven guidelines outlined by the FCTC will enable countries to protect the health of their citizens and reduce mortality and illness from tobacco.

\section{Strengths and limitations}

This study examines tobacco packaging and labeling legislation in countries that contribute the most numbers of smokers to the global burden from smoking across all six WHO regions. However, these findings are subject to at least four limitations. First, unofficial translations of country tobacco laws [14] were used to assess compliance with the FCTC provisions. Due to limitations of translation, certain wordings or expressions may not be accurately represented. However, these translations were carefully verified by in-country lawyers and experts, as well Campaign for Tobacco-Free Kids staff in Washington DC, and give a clear understanding of country tobacco laws. Second, this study examines tobacco regulations as written, not as practiced. Some countries may actually meet the FCTC requirements in practice, even though their laws do not. For example, Canada's health warnings are placed at the top of the PDA, even though this is not specified in the legislation. Conversely, some countries may have laws that are compliant with the FCTC requirements, but are not enforced. Some examples include Vietnam and the US, whose new laws have not yet come into full effect. Third, this study examines laws that pertain only to manufactured cigarettes. Fourth, the unavailability of verified translations of laws in many African and Eastern Mediterranean countries prevented us from including more countries from these regions in this study.

\section{Conclusions}

This study demonstrates that among countries that contribute the most to the global tobacco burden, there are still areas of nonalignment of tobacco laws with guidelines specified by article 11 of the FCTC. The gains made in global tobacco control in recent times can be consolidated by advocating for stronger tobacco regulations in compliance with the FCTC. Strong, effective, evidence-driven health warning labels are needed to protect and promote global public health.

\section{Abbreviations}

FCTC: Framework convention on global tobacco control; WHO: World health organization; PDA: Principal display area.

Competing interests

Both authors declare that they have no competing interests.

\section{Authors' contributions}

AA initiated the concept of the study, extracted and analyzed the data, and prepared the initial draft of the manuscript. JEC contributed to development of the methodology and the interpretation of results, and critically reviewed and revised the manuscript. Both authors read and approved the final manuscript. 


\section{Acknowledgments}

The tobacco legislation for this study was obtained from the Campaign for Tobacco-Free Kids through their website: www.tobaccocontrollaws.org. Additional up-to-date tobacco legislation for Viet Nam was provided by Steve Tamplin. JEC was supported by a grant from the Bloomberg Initiative to Reduce Tobacco Use to the Johns Hopkins Bloomberg School of Public Health.

Received: 23 August 2013 Accepted: 1 November 2013

Published: 6 November 2013

\section{References}

1. WHO MPOWER: A Policy Package to Reverse the Tobacco Epidemic. Geneva: World Health Organization; 2008. http://www.who.int/tobacco/mpower/ mpower_english.pdf.

2. Guidelines for Implementation of Article 11 of the WHO Framework on Tobacco Control (Packaging and labeling of tobacco products). http:// www.who.int/fctc/guidelines/article_11.pdf.

3. Hulit M: Marketing issues corporate affairs conference May 27, 1994 Manila. Richmond, Virginia: Philip Morris; 1994. Bates No. 2504015017/5042. http:// legacy.library.ucsf.edu/tid/jga42e00.

4. Fooks G, Gilmore AB: International trade law, plain packaging and tobacco industry political activity: the trans-pacific partnership. Tob Control tobaccocontrol-2012-050869 Published Online First: 20 June 2013. doi:10.1136/ tobaccocontrol-2012-050869.

5. Vardavas Cl, Connolly G, Karamanolis K, Kafatos A: Adolescents perceived effectiveness of the proposed European graphic tobacco warning labels. Eur J Public Health 2009, 19:212-217.

6. White $V$, Webster B, Wakefield M: Do graphic health warning labels have an impact on adolescents' smoking-related beliefs and behaviours? Addiction 2008, 103:1562-1571.

7. WHO: WHO Report on the Global Tobacco Epidemic: Warning about the dangers of tobacco; 2011. http://whqlibdoc.who.int/publications/2011/ 9789240687813_eng.pdf.

8. Wade B, Merrill RM, Lindsay GB: Cigarette pack warning labels in Russia: how graphic should they be? Eur J Public Health 2011, 21:366-372.

9. Abdullah AS, Yang T, Beard J: Predictors of women's attitudes toward world health organization framework convention on tobacco control policies in urban China. J Women's Health) 2010, 19:903-909.

10. Yang T, Wu Y, Abdullah AS, Dai D, Li F, Wu J, Xiang H: Attitudes and behavioral response toward key tobacco control measures from the FCTC among Chinese urban residents. BMC Public Health 2007, 7:248.

11. Miller $C L$, Hill DJ, Quester $P G$, Hiller JE: Response of mass media, tobacco industry and smokers to the introduction of graphic cigarette pack warnings in Australia. Eur J Public Health 2009, 19:644-649.

12. Wakefield MA, Hayes L, Durkin S, Borland R: Introduction effects of the Australian plain packaging policy on adult smokers: a cross-sectional study. BMJ Open 2013, 3(7). doi: 10.1136/bmjopen-2013-003175. Print 2013.

13. The world bank. http://data.worldbank.org/indicator/SP.POP.TOTL.

14. Campaign for tobacco-free kids. http://www.tobaccocontrollaws.org.

15. Glantz SA, Barnes DE, Bero L, Hanauer P, Slade J: Looking through a keyhole at the tobacco industry. The Brown and Williamson documents. JAMA 1995, 274:219-224

16. US Department of Health and Human Services, CDC, Coordinating Center for Health Promotion, National Center for Chronic Disease Prevention and Health Promotion, Office on Smoking and Health: The Health Consequences of Involuntary Exposure to Tobacco Smoke: A Report of the Surgeon General. Atlanta GA; 2006. http://www.surgeongeneral.gov/library/reports/ secondhandsmoke/report-index.html.

17. Romer D, Jamieson P, Ahern R: The catch 22 of smoking and quitting. In Smoking: Risk, Perception, and Policy. Edited by Slovic P. SAGE Publications; 2001.

18. Borland R, Wilson N, Fong GT, Hammond D, Cummings KM, Yong HH, Hosking W, Hastings G, Thrasher J, McNeill A: Impact of graphic and text warnings on cigarette packs: findings from four countries over five years. Tob Control 2009, 18:358-364.

19. Hammond D, Fong GT, McDonald PW, Cameron R, Brown KS: Impact of the graphic Canadian warning labels on adult smoking behaviour. Tob Control 2003, 12:391-395.

20. Hammond D, Fong GT, McNeill A, Borland R, Cummings KM: Effectiveness of cigarette warning labels in informing smokers about the risks of smoking: findings from the international tobacco control (ITC) four country survey. Tob Control 2006, 15(Suppl 3):iii19-25.

21. Hammond D, Fong GT, Borland R, Cummings KM, McNeill A, Driezen P: Text and graphic warnings on cigarette packages: findings from the international tobacco control four country study. Am J Prev Med 2007, 32:202-209.

22. Nimbarte A, Aghazadeh F, Harvey C: Comparison of current U.S. and Canadian cigarette pack warnings. Int Q Community Health Educ 2005, 24:3-27.

23. O'Hegarty M, Pederson LL, Nelson DE, Mowery P, Gable JM, Wortley P: Reactions of young adult smokers to warning labels on cigarette packages. Am J Prev Med 2006, 30:467-473.

24. O'Hegarty M, Pederson LL, Yenokyan G, Nelson D, Wortley P: Young adults' perceptions of cigarette warning labels in the United States and Canada. Prev Chronic Dis 2007, 4:A27.

25. Peters E, Romer D, Slovic P, Jamieson KH, Wharfield L, Mertz CK, Carpenter SM: The impact and acceptability of Canadian-style cigarette warning labels among U.S. smokers and nonsmokers. Nicotine \& Tobacco Research 2007, 9:473-481.

26. Fong GT CA, Brown KS, et al: Effects of the Canadian graphic warning labels among high school students: A quasi-experimental longitudinal survey. Presentation at the 2002 National conference on Tobacco or Health. San Francisco; 2002. http://ncth.confex.com/ncth/2002/techprogram/paper_6056.htm.

27. Borland $\mathrm{R}$, Yong $\mathrm{HH}$, Wilson $\mathrm{N}$, Fong GT, Hammond D, Cummings KM, Hosking W, McNeill A: How reactions to cigarette packet health warnings influence quitting: findings from the ITC four-country survey. Addiction 2009, 104:669-675.

28. Thrasher JF, Hammond D, Fong GT, Arillo-Santillan E: Smokers' reactions to cigarette package warnings with graphic imagery and with only text: a comparison between Mexico and Canada. Salud publica de Mexico 2007, 49(Suppl 2):S233-240.

29. Hammond D, McDonald PW, Fong GT, Brown KS, Cameron R: The impact of cigarette warning labels and smoke-free bylaws on smoking cessation: evidence from former smokers. Can J Public Health 2004, 95:201-204.

30. Hammond D, Fong GT, McDonald PW, Brown KS, Cameron R: Graphic Canadian cigarette warning labels and adverse outcomes: evidence from Canadian smokers. Am J of Public Health 2004, 94:1442-1445.

31. Datafolha Instituto de Pesquisas: $76 \%$ são a favor que embalagens de cigarros tragam imagens que ilustram males provocados pelo fumo; $67 \%$ dos fumantes que viram as imagens afirmam terem sentido vontade de parar de fumar $[76 \%$ are in favor of pictures on cigarette packs that illustrate the problems caused by smoking; $67 \%$ of smokers saw the pictures and say they made them want to stop smoking]. Opinião pública; 2002.

32. Graphic health warnings on tobacco packaging inspire smokers to quit the habit. http://hpb.gov.sg/hpb/default.asp?TEMPORARY_DOCUMENT= 2982\&TEMPORARY TEMPLATE $=2$.

33. The International Tobacco Control Policy Evaluation Project: Thailand. Waterloo, ON: The International Tobacco Control Policy Evaluation Project; 2010. http:// www.itcproject.org/projects/thailand/thexecsummaryadults07pdf.

doi:10.1186/1617-9625-11-23

Cite this article as: Awopegba and Cohen: Country tobacco laws and article 11 of the WHO Framework Convention on Tobacco Control: a review of tobacco packaging and labeling regulations of 25 countries. Tobacco Induced Diseases 2013 11:23.

\section{Submit your next manuscript to BioMed Central and take full advantage of:}

- Convenient online submission

- Thorough peer review

- No space constraints or color figure charges

- Immediate publication on acceptance

- Inclusion in PubMed, CAS, Scopus and Google Scholar

- Research which is freely available for redistribution 